\title{
The Problem of the Exegesis in Creative Writing Higher Degrees
}

\begin{abstract}
It has now become standard practice for there to be an exegetical component not only in creative writing $\mathrm{PhDs}$, but also in Masters and even Honours dissertations. In this paper we will examine the main kinds of exegeses currently being submitted and discussed including reflective/journal-based, 'theory' based, literary criticism, and historical or genre context - and attempt to evaluate their usefulness both for the student/writer and for the broader academic community.

We will be exploring such questions as: does current learning theory support the reflective or self-critical approach? Are current exegetical models (particularly the literary criticism model) overly embedded in an English Department idea of writing and writing theory? Does creative writing need to establish its own critical discourse, particularly through the exegesis? What kinds of students are doing these exegeses and how does our understanding of their assumed knowledges impact on developing models for critical work? Does current exegetical practice contribute to a growing theory of creative writing?
\end{abstract}

\section{First Introduction: What Problem?}

This paper speaks to a persistent sense of anxiety being expressed by academics, examiners and Research Higher Degree students in the field of Creative Writing. Our understanding of this anxiety is probably most clearly influenced by the relevant thread of articles in TEXT (1), but also comes from our professional engagements in the field - as supervisors, examiners and students. In particular, this sense of anxiety seems to be directed towards three main areas of concern: the validity of the exegesis, its necessity, and its usefulness.

Many Creative Writing Research Higher Degree students struggle with the validity of the exegesis during their years as a student. They tend to embrace, as do Dawson and Perry, the notion that "The literary work is itself an engagement with thought, philosophy and discourse." (Perry, 1998). Dawson argues that "the text produced in a Creative Writing class is not just a 'first order' practice ... It is already a dialogic engagement with theory, with language, with a range of social and cultural discursive formations." This categorisation of the creative work as always already research is often perceived to be at odds with the requirement for an exegetical or critical component and leads to the second key area of concern: the question of necessity. 
The tension between the status of the creative work as research that is being argued for in terms of research quantum (the creative project stands alone), and the model of the creative work as Research Higher Degree (which requires supporting documentation) leads students to question whether they should be required to write an exegesis in order to 'validate' their Creative Writing as research. Further, there is the growing question of the usefulness of particular kinds of exegetical practice both for the student and for the (imagined/potential) reader. As our research shows, and as international precursors of Australian Research Programs indicates, significant proportions of Creative Writing produced within an RHD are never published. How then are we to assess the usefulness of a growing body of work that seems to comment on the production of unpublished - perhaps unpublishable - works?

\section{Second Introduction: What Exegesis?}

Our initial research was focused on Creative Writing RHDs in three Queensland Universities: Griffith University (GU), University of Queensland (UQ) and Queensland University of Technology (QUT). The research consisted of consulting the exegeses (where available) of Creative Writing RHD students and analysing their content in terms of the discourses enacted. Where exegeses were not yet available in the libraries, the candidates and their supervisors were consulted as to the content of their exegeses.

At this time - and according to the evidence of this initial research - we believe we can distinguish four types of discourse most frequently being used in exegetical practice: First Order Journal Practice, Second Order Journal Practice, Literary Theory and Cultural Studies Theory.

Initially, we had expected that the notion of a journal discourse could be considered as singular. As we read more exegeses and abstracts it became apparent that there were two clearly distinctive 'types' of journal work being carried out. In defining these types of journal work we were not concerned with the style of the writing - its aesthetic - rather with its concerns and some idea of the relative 'usefulness' of the work for readers.

First Order Journal Work is an informal and anecdotal form of journal work. The kind of journal work we would be more inclined to call a diary and to consider private. The idea that these kinds of journals might be considered private comes not from some coyness on the part of the reader, but from our observation that this kind of journal work is relevant only to the writer, and even then quite possibly useful only during the writing of the work it refers to. First Order Journal Work is primarily concerned with the emotional relationship of the writer to the task of writing, or to the subject of the writing. It is a discourse concerned with the journal-writer's intuitive, instinctive, non-reflective experience of 'being a writer'. As such, this kind of journal work far too easily collapses into narcissism and endless auto-reflexivity. Later we talk in more detail about the problems of this kind of discourse, but for now we would like to point out that several writers who had engaged in this kind of writing intimated in discussion that they had 'faked' this aspect of their exegetical work, drawing on established ideas of authorship while being conscious of impersonating themselves as authors.

Second Order Journal Work is a more formalised type of journal writing, engaging as it does not only with the moment of writing, but the moments between writing the ongoing, reflective, critical and analytical learning process of 'being a writer' (where the 'writer' is not understood simply as someone who writes but is, instead, conscious of themselves as a subject actively engaged in developing their skills as a writer over time). Second Order Journal Work then, in comparison to First Order Journal Work, is meta-writing. It is writing about writing, writing that is self- 
conscious, evaluative, critical. It is journal work that asks questions about process, product, praxis and practice. It is journal work that can be drawn on by other writers who wish to understand, evaluate or interrogate their own writing practices. It displays an awareness not only of the student/writer's own model of writing, but those of other writers and thinkers. Importantly it displays that elusive quality that examiners and administrators are most insistent students demonstrate: a conscious and well-articulated awareness of the research practices in evidence in the creative work.

The other two discourses that dominate current exegetical practice are Literary Theory and Cultural Studies. It is our assertion that there are at least two reasons for this preponderance. The first is the idea that these disciplines are a 'neat fit' with Creative Writing. There is a largely unexamined perception that Creative Writing has a lot in common with Literary Theory and/or Cultural Studies. This is underpinned by the commonly-held awareness that 'good readers make good writers' and that these two disciplines contribute to the development of student/writers who are effective readers of both their own and other's work. Second, given the fledgling nature of Creative Writing as an RHD practice, most students are being supervised - by necessity - by academics with English Literature or Cultural Studies backgrounds. These supervisors do not always have a publishing history as creative writers. At times they become supervisors of Creative Writing RHD students because of a personal or professional interest in the practice of Writing, despite the lack of a publishing history in Creative Writing.

We feel it is important to note that while these disciplines - or particular aspects of them - may turn out to be a natural and comfortable fit with Creative Writing, it may also be that they are contributing to a body of Creative Writing RHD graduates who are imbued with a necessarily partial, eccentric - incomplete knowledge of the discourses and rhetoric of Literary Theory and/or Cultural Studies rather than a fuller knowledge of something newer that can more truly be described as Creative Writing discourse. It is apparent that many universities are aware of this partiality in terms of theoretical knowledge. In the University of Queensland's 'Guidelines for Examiners', for example, it is stated that a student's work "while engaging with issues of literary theory and criticism, will not necessarily display the kind of in-depth knowledge of contemporary theory that would be appropriate at this scholarly level" (UQ, 2002).

\section{First Body: Exhumation}

The following is a brief summary of the findings of the research, including tables which break down the exegetical practices of creative writing RHD students in the three universities (2). QUT graduates are not included in Appendix One since students at this university were not - until this year (2003) - required to write or submit an exegesis with their creative works.

Honours degrees have been included here for two main reasons. After discussions with the relevant course convenors it was discovered that the course structures for Honours and Research Masters degrees considered in this study were similar both within and across the three universities, typically consisting of a semester of coursework (during which students develop their creative and exegetical works) and a semester of research, resulting in the submission of a creative work and exegesis (3). Secondly, after reading the exegeses of the relevant Honours and MA students it was discovered that - despite producing much longer exegeses, with more detailed arguments - the MA students displayed a similar quality of argument and breadth of quantifiable research. 


\section{Queensland University of Technology (QUT)}

While Masters and Honours students have not - until this year - been compulsorily required to submit an exegesis with their creative work, two of the ten graduates to date chose to write and submit an exegetical work.

Philip: One of these was by a Masters student I supervised about five years ago. The exegesis addressed the literary context in which the creative work might best be considered. I was not satisfied with the quality of the exegesis, since it was written by a psychology $\mathrm{PhD}$ who insisted on attempting literary theory despite having had little literary critical background. My preference to take on students in the MA(Research) who could write creatively at a high level, but did not necessarily have the training to write a sophisticated literary exegesis was one reason I did not push for a mandatory exegetical component for several years.

The other reason was based on the following question (which I suggest cannot be lightly dismissed). In insisting on an exegetical component at the Masters level (I have no problem with it being mandatory at the $\mathrm{PhD}$ level, as this is often a pathway to an academic career) are we not undercutting the current argument that creative writing/creative practice is equivalent to noncreative theses in intellectual and cognitive grasp, in comprehensiveness, in constructing new syntheses and advancing new knowledge? That is, are not Creative Writing RHD projects legitimate research output in their own right?

Nike: The second student was an Honours student with an undergraduate background in journalism. As a student without a strong background in Creative Writing I felt it was imperative that this student engage in critical work during the course of her research/writing. This was largely precipitated by initial meetings with the student during which she struggled to articulate her problems as a writer. As a process and critique document, the exegesis became a tool for her to discuss what difficulties she was encountering during the writing process, why they arose and what strategies she employed in overcoming them.

While there are no graduated PhDs from QUT, Venero Armanno gave his final seminar on the 28th March this year and Donna Lee Brien will give her final seminar in May. Armanno's PhD consists of three screenplays adapted from his own novels, and an exegesis discussing the effects of the respective relationships of the producer/s, novelist and screenwriter to the screenplays. Brien's exegesis analyses the issue of the fictionalised biography that is based, where possible, on the historical record. It engages with current critical debate around the fictionalised biography as a genre, as well as articulating some of the processes involved in the writing of a fictionalised biography.

\section{University of Queensland (UQ)}

Twenty-seven graduates of the MA(Research) in Creative Writing were available through the UQ library at the time of this paper (see Appendix One). The MA(Research) at UQ requires that students write and submit a book-length creative work and a critical essay of around 10,000 words. According to the 'Guidelines for Examiners' the critical essay should "take the form of a critical reflection upon the dissertation, upon the process of writing, or upon the context and conditions of writing" (UQ, 2002). The guidelines further advise that 
"although the Dissertation and the Essay are both essential components of the assessment you are asked to give major weight to the Dissertation."

As can be seen in Table 1 there is a preponderance of Cultural Studies or Literary Theory discourse in the exegeses that have been produced at UQ to date (as at Griffith). While the journal work that is in evidence is generally First Order Journal Work, this seems to be largely because it is not written to carry the weight of argument in the essay - rather as anecdotal reinforcement of a theoretical point, much in the way that the biographical anecdote is often used in ficto-criticism as a way of reinforcing the theoretical via the personal.

\begin{tabular}{|c|c|c|c|c|}
\hline & UQ & Griffith & & Overall \\
\hline & & BA(Hons) & PhD & \\
\hline $\begin{array}{l}\text { Literary } \\
\text { Theory }\end{array}$ & 14 & 3 & 2 & $\mid 19$ \\
\hline $\begin{array}{l}\text { Cultural } \\
\text { Studies }\end{array}$ & 12 & 10 & 3 & 25 \\
\hline $\begin{array}{l}\text { First } \\
\text { Order } \\
\text { Journal } \\
\text { Work } \\
\end{array}$ & 10 & 0 & 0 & 10 \\
\hline $\begin{array}{l}\text { Second } \\
\text { Order } \\
\text { Journal } \\
\text { Work }\end{array}$ & 16 & 6 & 4 & 26 \\
\hline Other & 2 & 0 & 5 & 7 \\
\hline Totals & 44 & 19 & 14 & \\
\hline $\begin{array}{l}\text { Number } \\
\text { of } \\
\text { Students } \\
\text { in Survey }\end{array}$ & 27 & 11 & 6 & \\
\hline
\end{tabular}

Where Second Order Journal Work occurs, it is more likely to be a kind of literary analysis of the student/writers' own work, much in the same vein as that carried out in the literary analysis of works by other authors. Typically, the critical essays were principally comprised of an analysis of two or more works by authors other than the candidate whose work the student/writer felt their own work was similar to, in the same genre as, or a development from. Analysis of the student/writers' own work typically engaged in analysis of their own work as a product rather than as a process.

\section{Griffith University (GUGC)}

There are six graduates from the $\mathrm{PhD}$ program in Creative Writing to date at Griffith University. Although the theses for two of these graduates are on restricted access until 2004 we were able to garner information about the content of the exegeses in question, as well as the relationship between the exegeses and creative works, from discussion with the relevant writers as well as with Nigel Krauth - the head of Creative Writing and co-supervisor of at least four of the graduated $\mathrm{PhD}$ students. While this information is partly addressed in what follows the small number of graduates and the limited current availability of the 
theses meant that these have not been considered in as much detail as the Honours and MA(Research) graduates.

There is no MA(Research) in Creative Writing available at Griffith, although students can embark on an MPhil (no graduates to date). There have been, however, 11 honours graduates who have engaged in a similar one-year program to that undertaken during the MA(Research) at UQ. Preliminary analysis of our research indicates that Honours students in the Griffith program engage in a similar breadth and quality of research as that carried out by the UQ MA(Research) students, despite producing significantly (50\%) shorter exegeses with a concomitant reduction in the depth of argument. Table 1 shows the average and median number of bibliographic entries in the MA and Honours exegeses completed at the respective universities. On average, MA students cited approximately 6 more entries than Honours students. The median, however, shows that Honours students typically cited 15 more entries than Masters students. This analysis of quantifiable, recorded research indicates that candidates in these programs engaged in a similar amount of research. Further, in reading across these exegeses it becomes clear that, on average, students engaged in a similar range of exegetical adeptness. That is, their writing was of a similar quality overall.

\begin{tabular}{|l|l|l|}
\hline \multicolumn{2}{|l|}{ Table 2 - Bibliographic Records } \\
\hline Number of Entries & Average & Median \\
\hline \hline UQ - MA (Research) & 74.44 & 45 \\
\hline Griffith - BA(Hons) & 68.6 & 60 \\
\hline Combined & 71.52 & 52.5 \\
\hline \hline
\end{tabular}

\section{Summary of results}

Table 1 is a summary of the types of discourses used in the RHDs surveyed. As can be seen, around $50 \%$ of UQ students engaged in Literary Theory or Cultural Studies discourse while around $25 \%$ of Griffith Honours students and $33 \%$ of $\mathrm{PhD}$ students engaged in Literary Theory, tending more towards the use of Cultural Studies discourse (Almost all of the Honours students and half of the $\mathrm{PhD}$ students). Importantly, all of the works surveyed engaged in two or more discursive practices and it is often in the interaction or collision of pre-existing discursive practices that the most intriguing work was in evidence. Confirming, for us, Barthes' argumentthat truly interdisciplinary work changes the object of study so that it "is experienced only in an activity of production ... it cannot stop ... its constitutive movement is that of a cutting across" (Barthes, 1977: 157 emphasis in original).

The following tables (Tables 3 and 4) summarise some of the other relevant detail that was uncovered in this initial survey. Table 3 looks at comparative lengths of creative works and exegeses in the MA(Research) at UQ and the BA(Hons) at Griffith. Interestingly, despite the requirement at UQ for an exegesis of around 10,000 words, most students wrote around 12,000 words. The average length of exegesis at UQ was 15,523 words. As expected, and despite the similar timeframes, MA students produced longer creative and exegetical works.

\begin{tabular}{|l||}
\hline Table 3 - Comparative Lengths of Creative Works and \\
Exegeses \\
\hline \hline
\end{tabular}


Nike Bourke \& Philip Nielsen TEXT Special Issue No 3

\begin{tabular}{||l||l|l|l|l||} 
Length of Works & \multicolumn{1}{|l|}{ Creative Work } & \multicolumn{1}{l||}{ Exegeses } \\
\hline \hline & Average & Median & Average & Median \\
\hline $\begin{array}{l}\text { UQ - MA } \\
\text { (Research) }\end{array}$ & 41279.6 & 30000 & 15523 & 12000 \\
\hline $\begin{array}{l}\text { Griffith - BA } \\
\text { (Hons) }\end{array}$ & 17461 & 16250 & 6273 & 5750 \\
\hline Combined & 29370.3 & 23125 & 10898 & 8875 \\
\hline
\end{tabular}

Table 4 is concerned with the types of creative work undertaken by students. Some students - as can be surmised - engaged in more than one form of creative work. Typically, theses that used a combination of works were combined poetry and short story collections. Interesting as well, although not shown on this chart, is the fact that despite the requirement that students write a book-length creative work, 8 students wrote works that were less than 30,000 words in total (4) (the minimum for entry into the Vogel/Australian Literary Award and a fair estimation of the minimum length for a monograph publication in Australia). This represents just under one third - $33 \%$ - of the students surveyed here.

As can be seen, the majority of students chose to engage in fictional prose writing - producing novels or novellas. The next most popular choice is the poetry collection. Again, what doesn't show up in this data, but is nevertheless of some note, is the handful of theses where the critical and creative components were combined. There were three of these. Each combined prose fiction with theoretical discourse. One of these was a PhD produced at Griffith University; the writer is currently engaged in unravelling the two threads, partly in order to more successfully seek publication of the creative work/novel.

\begin{tabular}{|c|c|c|c|c|}
\hline \multicolumn{5}{|c|}{ Table 4 - Types of Creative Works } \\
\hline & \multirow[t]{2}{*}{ UQ } & \multicolumn{2}{|l|}{ Griffith } & \multirow[t]{2}{*}{ Totals } \\
\hline & & BA(Hons) & PhD & \\
\hline Novel or novella & 16 & 7 & 4 & 27 \\
\hline Poetry & 5 & 2 & 0 & 7 \\
\hline Short Stories & 2 & 2 & 0 & 4 \\
\hline Screenplay & 2 & 0 & 0 & 2 \\
\hline Stageplay & 1 & 0 & 1 & 2 \\
\hline Non-Fiction & 2 & 0 & 1 & 3 \\
\hline Radio Script & 1 & 0 & 0 & 1 \\
\hline
\end{tabular}

\section{Second Body: Autopsy}

While many universities state - or imply - that works considered for examination are being assessed, at least in part, in terms of their publishability, relatively few MA(Research) or Honours creative works have gained publication. Griffith Honours students are not required to write a 'book-length' creative work, which certainly affects the likelihood of the works gaining publication. Nevertheless, anecdotal evidence indicates that a small number of these writers have been successful in publishing extracts, individual short stories or individual poems 
from their creative works. Of the $27 \mathrm{MA}$ (Research) works, four have been published - approximately $15 \%$ of the total. Of these four, at least two candidates had previously had monograph publications. Unfortunately, at this time we have little quantifiable or anecdotal evidence of publication rates for extracts (eg: single poems or short stories) from these theses.

These low publication rates are not a peculiarly Australian problem. In discussing North American MFA programs, Hayes asserts that, "none of the Faculty members I interviewed seriously considered that more than a handful of students would become full-time writers. Approximately three percent of MFA manuscripts find a publisher and teachers thought it much more likely that a second or third attempt by their top students would be successful." (Hayes, 1998. Emphasis added)

Publication statistics - problematic and possibly misleading as they are, given the far lower number of graduates in this sample - are already much stronger for $\mathrm{PhD}$ graduates. Of the six $\mathrm{PhD}$ graduates in this sample, three of the novels have already been published or have been accepted for publication and the one stageplay professionally produced after gaining funding through the Australia Council. However, it is important to note that this rate of 'success' may be a direct result of the fact that students are far more likely to be accepted into a $\mathrm{PhD}$ program if they have a strong pre-existing publication record (it is, for example, the practice at QUT to prefer candidates with a publication track record). Indeed, of the six PhD graduates in this sample, two had previously published at least three monographs.

\section{First Conclusion/Findings}

\section{Two Kinds of Students:}

In looking back over these initial inquiries, looking for patterns and predilections, and considering the anecdotal evidence of those students, supervisors and examiners who were consulted during the process of collating the information one thing, in particular, became clear: there are, essentially, two kinds of students engaging in Creative Writing RHDs, with two distinct sets of desired outcomes from study.

The first group we have called the professional students. This group consists of students who demonstrate the capacity to write professionally in the creative mode. Typically they desire only to write in the creative mode and do not wish to pursue an academic career. These kinds of students often struggled with the writing of their exegetical work, lapsing frequently into First Order Journal Work. Where they engage with critical discourses it is often in a compromised and somewhat naive manner. In discussion with these students it becomes clear that they actively resisted writing the exegesis during their studies and - perhaps more importantly - that even well after completion (several years in some cases) they continue to regard the exegesis as a 'pointless' exercise, which they managed to complete at -what they consider to be - a mediocre or merely adequate critical level.

The second group we have called the academic students. These students demonstrate both the capacity and the desire to write both critically or academically and creatively. Many of these students are interested in the option of an academic career. These kinds of students often enjoyed the exegetical work in its own right and were inspired by it in their creative work. As a result of their enthusiasm and/or relative confidence with the theoretical/academic writing they were more likely to be confident and intellectually adventurous in their exegeses. 


\section{What Discourse?}

It is also clear that the notion of a Creative Writing discourse is developing - as would be expected in these early years - in a somewhat ad hoc manner. It is apparent that there are many factors that enter into the capacity and will of the RHD student to contribute to the development of such a distinctive discourse, including but not restricted to the combined academic and professional (creative writing) backgrounds of supervising academics.

There is a distinct - and worrying - lack of synthesis or agreement as to what kinds of theoretical discourses can and should be used in creative writing exegeses. In particular, while the emphasis on Literary Theory or Cultural Studies provides an initial sense of clarity and focus it soon becomes clear that the way in which these discourses are being applied in Creative Writing RHDs varies significantly across universities as well as within them. This lack of synthesis in the ways in which these discourses are adopted or applied leads to the development of an erratic and somewhat compromised sense of Creative Writing as a discipline and/or set of discourses. A development that remains largely dependent on the professional and academic background of supervising academics and RHD students.

It may well be that the uncertain nature of Creative Writing as a discourse is also part of its unique value and appeal, but we think there is also a strong need - as well as an expressed desire - for some measure of agreement. In part this consensus is necessary in order to be able to argue for recognition - at a national level - of Creative Writing as a discipline, for recognition of Creative Works as research quantum, for Creative Writing discourses to evolve beyond their current level. Given the somewhat nomadic nature of academic life for many of us, it would also be useful for academics and students to have a shared knowledge base from which to work.

There is also an ongoing need - at School, University and National levels - to justify and quantify the Creative Arts as Research. Ongoing debates regarding this are often seen, by RHD students, to be at odds with the requirement for an exegesis. If, the argument goes, academics insist that their own published creative works should be given status and recognition as research in their own right, why should a different set of criteria apply to the creative work produced as part of an RHD? This question sets in play a series of connected questions: is an unpublished (but ostensibly 'publishable') novel or collection of poems somehow considered less research than its published equivalent? How are examiners meant to assess an already-published work in terms of its publishability?

Nike: My own experience is, perhaps, illustrative here. The creative component of my $\mathrm{PhD}$ - The Bone Flute - was completed and published well before the final submission of the $\mathrm{PhD}$ as a whole. When I was preparing my twinned manuscripts for submission I found myself in a quandary - should I print out a manuscript version of the novel on A4 paper, double-spaced with the obligatory margins, or simply hand in the published version? In the end I decided to hand in the published version of my novel. This was largely precipitated by my feeling that to produce a manuscript version of the novel was somehow to 'fake' its status as in-process. Certainly I understood that the examiners might find the finiteness of the published novel a difficulty (how to offer - or demand - revisions of a sealed, completed object?). Nevertheless, corrections or emendations offered on the basis of a manuscript version would (I believed) only seem to be less problematic. As a result of my decision - in consultation with my supervisors - the examination of my thesis was delayed as various people in the chain between myself and the examiners worried at 
the novel, made phone calls, referred to guidelines. I was asked whether, should it be necessary, I could prove that I had written the novel during the period of my study (I had been enrolled in the $\mathrm{PhD}$ for a little over four years. The novel had been published less than a year prior to submission). The assumption that underpinned the anxious phone calls from the examinations office centred around the presumption that a $\mathrm{PhD}$ is assumed to be an unpublished work. Recently I had the opportunity to informally discuss with my examiner their quandary in assessing an alreadypublished novel. She informed me that mine was not the first RHD she had assessed that included a published work and expressed her concern that it was perhaps impossible to fail such an object since to fail it implies that it is 'unpublishable'. How could one possibly declare that a published work is unpublishable!

\section{Second Conclusion - Towards Solutions}

Given the anxiety over the exegesis, and the variations in quality, theoretical relevance, theoretical engagement and perceived relevance for both students and supervisors of current exegetical practice it is our - perhaps somewhat contentious - assertion that the types of students we have categorised as professional students should not be required to write exegeses. Rather, we should focus on developing two streams of study within the Creative Writing field to cater to the two distinctive types of students currently engaging in Creative Writing RHDs (See Table 5).

\begin{tabular}{|l||l||}
\hline \multicolumn{2}{|l||}{ Table 5 - Two Courses of Study } \\
\hline MA (Research) & MFA \\
\hline $\begin{array}{l}\text { Entry by creative work and } \\
\text { academic record, ie: by } \\
\text { demonstrated ability in both } \\
\text { areas via, for example, folio } \\
\text { and Grade Point Average. }\end{array}$ & Entry by folio of creative \\
\hline $\begin{array}{l}\text { Final assessment by exegesis } \\
\text { and book-length creative } \\
\text { work of publishable } \\
\text { standard. }\end{array}$ & $\begin{array}{l}\text { Final assessment by book- } \\
\text { length creative work of } \\
\text { publishable standard. No }\end{array}$ \\
\hline $\begin{array}{l}\text { Can lead to entry into a PhD } \\
\text { program and/or an academic } \\
\text { career path }\end{array}$ & $\begin{array}{l}\text { Does not lead to entry into a } \\
\text { PhD program and/or an } \\
\text { academic career path }\end{array}$ \\
\hline
\end{tabular}

The pragmatic problem with this model is that universities are pushing for academics to work towards the completion money gained from Research Higher Degrees. Currently the MFA is not a research degree and unless it can be categorised as a research, or full fee-paying degree, it is unlikely to be supported. On the other hand, if Creative Writing departments are successful in arguing for recognition of stand-alone creative works as research quantum it may become much easier to argue for recognition of the MFA as a research program.

\section{Creative Writing Discourse/Theory}


We need to constantly and consciously examine - although not reject - the adoption by RHD students of Literary Theory and/or Cultural Studies theoretical discourses (or others). This is key to our success in establishing Creative Writing as a recognisable and recognised discipline area (5). As an emerging discipline we need to be continually aware that the work produced by our RHD students is a key element in establishing Creative Writing as an academic discipline and as a set of discursive practices. We need to ensure that Creative Writing continues to develop its standing as an independent research area, with its own set of critical issues and debates that can intersect with but not disappear into other discipline areas.

It is important to notice, for example, that a significant number of students who engaged in Literary Theory in their exegeses applied the same techniques of analysis and reading to their own works. Leaving aside the inherent problems of self-analysis - of narcissism, objectivity, subjectivity and self-reflexivity - we would like to draw attention to the fact that when using Cultural Studies or Literary Theory students treat their own work as a sealed and completed object. What is always lost in this treatment of their own work as object is the writing, what replaces writing is the act of reading. If we are to develop a unique and recognisable set of discourses that can rightly be called Creative Writing, that is identifiably different to Literary Theory or Cultural Studies, we must recognise that this movement should not take place. Creative Writing, as an appellative, recognises what we need to keep constantly in mind - that we are a discipline whose principal concern is with the development, critique and articulation of process rather than product.

We need to actively discourage students from engaging in the purely 'anecdotal' mode of journal work we have here christened 'First Order', as it demonstrates only a minimal - at times negligible - usefulness to Creative Writing as a field of research. This kind of practice often results in journal work of a highly individual and eccentric process leading to the writing of an unpublished, and perhaps even unpublishable, creative work. Sometimes these kinds of texts 'work' as a form of memoir for well-known, widely published authors who have a ready audience for everything they write. Authors such as Stephen King, Graham Greene and Annie Dillard - just to name a few - have written quite successful accounts of their writing lives. Nevertheless, we should be aware that these works are received in the public domain more as autobiographical works in their own right than as exegetical practice that relates principally to another of their own creative works. Also, these works are received and read with the knowledge that they were written by authors who have well-established careers as published authors - as compared to the typical MA student who may not have published anything and whose accompanying creative work is unlikely to be published.

Perhaps we should also bear in mind the suggestion that this kind of self-reflexive work may be inherently limited from a learning and knowledge-theory point of view. Polanyi's work on tacit knowledge, for example, suggests that we can know more than we can tell. According to Polanyi there are two mutually exclusive dimensions of knowledge. Focal Knowledge, which is knowledge about the object or phenomenon in focus (knowing that), and Tacit Knowledge, which is used as a tool to handle or improve what is in focus (knowing how). These two types of knowledge, however, can only become useful or useable through the integration of knowledge, a skill which requires a knowledge about knowledge as integrated. He adds that that which can be successfully expressed - focal knowledge - is only the tip of the iceberg and that all knowledge is either tacit or rooted in tacit knowledge.

As an articulation of the writing process, First Order Journal Work often fails in its goal. More often than not these kinds of journal practices devolve into articulations of the most mundane practices of the writer in the act of not writing - 
in driving, washing up, weeping, drinking coffee. Instead of examining and critiquing these moments of a writerly life - or of connecting them to the act of writing (as would be the case in Second Order Journal Work) - First Order Journals seek simply to present the life, leaving the reader to bridge the gap between the life and the writing. It is our assertion that it is the job of the student/writer - in this exegetical instance at least - to attempt to bridge that gap in knowing.

\section{Notes}

1. See, for example, Brady, Kroll, Krauth, Dawson (1998 \& 2001), Perry (1998). Return to paper.

2. Appendix One gives a listing of all the exegeses consulted in the course of this paper. Return to paper.

3. Both the MA (Research) at UQ and the BA (Hons) at Griffith involve one year of full-time study or two years part-time. According to information provided on their website, the UQ Masters in Creative Writing consists of two compulsory courses and submission of a thesis. he courses are assessed on a pass/fail basis. The BA (Hons) at Griffith consists of 40 credit points (one semester's full-time load) of coursework and submission of a significantly smaller thesis (approximately $50 \%$ - see Table 3). Assessment for the final classification of the Honours degree is based on an Honours Weighting Average (HWA) that takes into consideration grades achieved across the whole year (ie: coursework and thesis combined) and the thesis. Return to paper.

4. Or, for poetry, collections of less than 50 pages. Return to paper.

5. I was reminded recently by a colleague at another university that many consider this fear of being subsumed into Literary Theory slightly paranoid, if not ridiculous. Those who are supervising students in the context of an English department, for example. This is not, however, the case nationwide. Creative Writing is taught in a plethora of diffferent contexts - in Creative Industries, in Philosophy, in Cultural Studies, in Professional Arts Schools - in short, across a diverse range of disciplinary umbrellas. This diversity can be a source of strength, but we believe it is another reason why we should be wary of accepting, for example, that any particular theoretical domain has a "natural" right of ascension in Creative Writing RHD work. Return to paper.

\section{Appendix One}

Theses by Author Surname and Exegesis Title

\section{Griffith University - PhD}

\begin{tabular}{||l|l||}
\hline Name & Exegesis Title \\
\hline \hline Baranay & $\begin{array}{l}\text { Sun Square Moon: An exegesis and } \\
\text { accompanying novel }\end{array}$ \\
\hline \hline Beresford-Plummer & $\begin{array}{l}\text { The individual writer and desire in theatrical } \\
\text { praxis : a case study of the play Body Parts }\end{array}$ \\
\hline \hline Bourke & $\begin{array}{l}\text { From the Cradle to the Grave: A Novel and } \\
\text { Exegesis }\end{array}$ \\
\hline Roberts & Writing Time: An Exegesis \\
\hline \hline Russell & $\begin{array}{l}\text { Elements and implications of a constructive } \\
\text { hypertext story-writing pedagogy for adolescents }\end{array}$ \\
\hline \hline Wise & $\begin{array}{l}\text { The Turns of Engagement: A Thesis/Novel on } \\
\text { the circumstances of writing }\end{array}$ \\
\hline
\end{tabular}

\section{Griffith University - BA(Hons)}

\begin{tabular}{||l|l||}
\hline Name & Exegesis Title \\
\hline \hline & Beyond the Snapshots: Writing the Gold Coast
\end{tabular}




\begin{tabular}{||l||l||}
\hline Ball & \\
\hline \hline Bourke & Becoming Angels: Women Writing Cyberspace \\
\hline \hline Breen & $\begin{array}{l}\text { Travelling Ontologies, Methodologies and } \\
\text { Figurations: Exploring nomads, writers, } \\
\text { cyborgs, and rhizomes in postmodern culture, } \\
\text { theory and practice }\end{array}$ \\
\hline \hline Cruickshank & Arriving at the Site of Story \\
\hline \hline Guest & For All That She Dreamed: Women's Writing \\
\hline Isakhan & $\begin{array}{l}\text { The Demeter and Persephone Effect: Some } \\
\text { Nineteenth \& Twentieth Century } \\
\text { Reinterpretations }\end{array}$ \\
\hline \hline Jay & The White Guy: Masculinity, Voice and Writing \\
\hline \hline Shepherd & Where the Dust Particles Dance \\
\hline \hline Zygarlicki & $\begin{array}{l}\text { Fossil: An Exegesis to accompany the book- } \\
\text { object Fossil }\end{array}$ \\
\hline \hline
\end{tabular}

\section{University of Queensland - MA(Research)}

\begin{tabular}{|c|c|}
\hline Name & Exegesis Title \\
\hline Banks & Stress as a Territorial Animal \\
\hline Barclay & $\begin{array}{l}\text { From Prose Fiction to the Stage: the adaptation } \\
\text { of John Gardner's Grendel, into the stage work } \\
\text { Grendel Grendel: A Black Comedy }\end{array}$ \\
\hline Bellear & $\begin{array}{l}\text { The Daily Business of working at writing and } \\
\text { survival }\end{array}$ \\
\hline Bond & $\begin{array}{l}\text { Wrestling the Blue Cactus: Grappling for } \\
\text { meaning through story and the self: writing } \\
\text { depressive illness }\end{array}$ \\
\hline Boyle & $\begin{array}{l}\text { The Writing of Call Me Jimmy: the rationale } \\
\text { for choosing my subject; an insight into the } \\
\text { research; and the influence of new journalism } \\
\text { on my writing style }\end{array}$ \\
\hline Bricknell & It Was A Good Idea At The Time \\
\hline Cadzow & $\begin{array}{l}\text { The Writing Dead: Reading and Writing a } \\
\text { Novel in the Age of the Death of the Author }\end{array}$ \\
\hline Carleton & Mr Hare's Seraglio \\
\hline Curran & The Drummer \\
\hline Dawson & The Artifice of Fiction \\
\hline Duke & $\begin{array}{l}\text { The Writing of With Barbarian Ghosts, An } \\
\text { Essay in Four Parts: Origin, Ancestry, Themes } \\
\text { and Strategy }\end{array}$ \\
\hline Fleming & Aural History \\
\hline George & $\begin{array}{l}\text { The Journey of the Narrative: Re-reading } \\
\text { ecriture feminine and the Experience of } \\
\text { Writing the Maternal }\end{array}$ \\
\hline Imlah & $\begin{array}{l}\text { Questions of Representation, authenticity and } \\
\text { identity in the treatment of Aboriginal English } \\
\text { and the historical subtext of The Dormitory }\end{array}$ \\
\hline Lea & Flight Animals \\
\hline MacColl & No Safe Place \\
\hline Marin & $\begin{array}{l}\text { A Personal Statement on the Writing of Lemon, } \\
\text { Lime and Bitters }\end{array}$ \\
\hline Martin & Into the Millennium: The Never Ending Novel \\
\hline
\end{tabular}


Nike Bourke \& Philip Nielsen TEXT Special Issue No 3

\begin{tabular}{|c|c|}
\hline & (Reflections on Closure) \\
\hline Munro & $\begin{array}{l}\text { An Investigation into the Poetics of Stages of } \\
\text { Body: The Writing of A Poem }\end{array}$ \\
\hline Ogden & Reflections on Writing \\
\hline Olsson & $\begin{array}{l}\text { In One Skin: A Critical Reflection on its } \\
\text { Genesis and Evolution }\end{array}$ \\
\hline Philp & An Investigation of Storytelling \\
\hline Singh & $\begin{array}{l}\text { Men and Women and Gold: The Problem of } \\
\text { Desire in the Writing of Precious }\end{array}$ \\
\hline St George & $\begin{array}{l}\text { Dirt Into Gold: The Alchemy of Temporary } \\
\text { Madness }\end{array}$ \\
\hline Verney & The Women Came and Went \\
\hline Wilkins & untitled exegesis \\
\hline Zervos & Cyberpoetry \\
\hline
\end{tabular}

Queensland University of Technology

\begin{tabular}{|l|l|}
\hline Name & Exegesis Title \\
\hline \hline Ashman & Unfinished Business - A Critical Reflection \\
\hline \hline Chai & untitled exegesis \\
\hline
\end{tabular}

Return to paper.

\section{References}

Barthes, Roland. (trans Stephen Heath) Image-Music-Text. New York, Hill \& Wang, 1977. Return to paper.

Brady, Tess. 'A Question of Genre: de-mystifying the exegesis' in TEXT, Vol 4, No 1. April 2000.

Return to paper.

Dawson, Paul. 'The Function of Critical Theory in Tertiary Creative Writing Programmes' in

Southern Review, Vol 30, No 1, 1997, 70-80.

Dawson, Paul. 'Writing Programs in Australian Universities: Creative Art or Literary Research?' in TEXT, Vol 3, No 1. April 1999. Return to paper.

Dawson, Paul. 'Creative Writing in Australia: The Development of a Discipline.' in TEXT, Vol 5, No 1, April 2001. Return to paper.

Krauth, Nigel. 'The Preface as Exegesis.' in TEXT, Vol 6, No 1, April 2002. Return to paper.

Kroll, Jeri. 'Creative Writing as Research and the Dilemma of Accreditation: How do we prove the value of what we do?' in TEXT, Vol 6, No 1, April 2002. Return to paper.

Griffith University. 'Bachelor of Arts (Honours)'.

www.griffith.edu.au/school/art/Courses/BAhonsdetails.html, accessed 25th March, 2003. Return to paper.

Hayes, Susan. 'A Better Class of Writing: Some Reflections on the MFA Program in North America' in TEXT, Vol 2, No 2, October 1998. Return to paper.

Perry, Gaylene. 'Writing in the Dark: Exorcising the Exegesis' in TEXT, Vol 2, No 2, October 1998. Return to paper.

Polanyi, Michael. Personal Knowledge: Towards a Post-Critical Philosophy. Chicago, University of Chicago Press, 1974. Return to paper.

Polanyi, Michael. The Tacit Dimension. New York. Doubleday \& Co (1966) and Massachusetts. Peter Smith, 1983. Return to paper.

University of Queensland. Department of English. 'Guidelines for Examiners.' (Letter sent with MA(Research) theses for examination), 2002. Return to paper.

University of Queenlsand. 'Master of Philosophy in Creative Writing.'

www.emsah.uq.edu.au/postgraduate/higher_degrees/mpcw.html, accessed 25th March, 2003.

Return to paper. 
exegesis. The novel The Bone Flute was the winner of the Queensland Premier's award for Emerging Author in 2000, and short listed for the Commonwealth Writers Award for Best First Book in the Asia-Pacific Region in 2001.

Philip Neilsen has published several books of poetry, novels for children and a monograph on David Malouf, and he has edited several anthologies. His most recent novel is Edward Britton (2000), co-written with Gary Crew. He is associate professor and head of creative writing and cultural studies at QUT. He is currently editing a collection of creative non-fiction with Donna Brien, and supervising several PhDs and MAs in creative writing.

TEXT Special Issue

No 3 April 2004

http://www.griffith.edu.au/school/art/text/

Editors: Julie Fletcher \& Allan Mann

General Editors: Nigel Krauth \& Tess Brady

Text@griffith.edu.au 